Revista Eletrônica Geografar, Curitiba, v. 2, Resumos do VI Seminário Interno de Pós-Graduação em Geografia, p. 51-51. Junho/2007

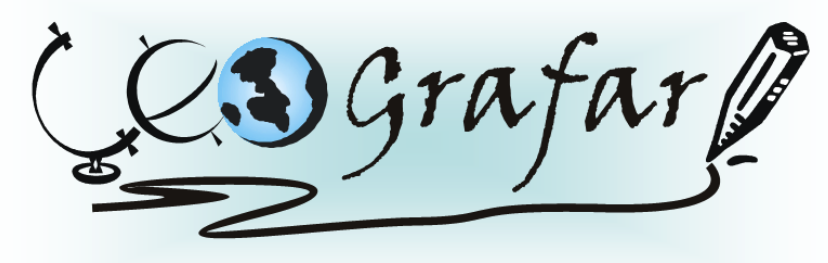

Revista Eletrônica do Programa de Pós-Graduação em Geografia - UFPR

\title{
A PAISAGEM SONORA E O FANDANGO CAIÇARA DA ILHA DOS VALADARES: PERCEPÇÃO E MEMÓRIA NA CONSTRUÇÃO DO ESPAÇO
}

\author{
MARCOS ALBERTO TORRES ${ }^{1}$
}

A ponte e as águas são os elementos que separam a ilha dos Valadares da cidade de Paranaguá. Apesar da proximidade - cerca de 400 metros do centro urbano - esses lugares possuem características diferentes na paisagem. O que nos interessa aqui é a paisagem sonora, marcante na ilha pela sua peculiaridade mais próxima do natural. Outro elemento importante na ilha é a presença do fandango, uma manifestação da cultura caiçara, que vê ao longo dos anos, as transformações espaciais e políticas que a forçam a buscar formas alternativas de subsistência, além das já tradicionais como a roça e a pesca. Dentro de uma cultura, a música serve para reafirmar valores dentro do grupo, e ajudar na associação de suas existências a objetos próximos. O mundo apreendido é cantado e musicalizado. Os valores do grupo são então repassados nas canções, assim como suas percepções e interações com o meio. O músico parte do "eu", sentindo e experimentando a paisagem, faz suas relações com a vida, e repassa para suas melodias e canções. A relação do músico com o espaço onde vive, resulta no melhor registro permanente de sons do passado: a música. Assim, ela será utilizada nesse projeto como um guia para o estudo das modificações nos hábitos e nas percepções auditivas. Através desse apoio que a música oferece, pretendemos fazer uma análise da paisagem existente na memória dos tocadores de fandango da ilha dos Valadares, e da paisagem atual percebida por eles, esta, apoiada também em mapas mentais e registros de entrevistas.

PALAVRAS-CHAVE: paisagem sonora, percepção, memória.

${ }^{1}$ Mestrando em Geografia - UFPR - email: torresmarcos@hotmail.com

Orientadora: SALETE KOZEL 